DOI https://doi.org/10.18551/rjoas.2017-11.27

\title{
SPECIAL ECONOMIC ZONES AS FORMS OF PUBLIC-PRIVATE PARTNERSHIP IN THE TERRITORIAL ASPECT OF INDUSTRIAL AGGLOMERATIONS
}

\author{
Popova Y. \\ Ocean University of China, Dalian \\ Komissarova V.* \\ Vladivostok State University of Economics and Service, Vladivostok, Russia \\ *E-mail: valeriya.komissarova@vvsu.ru
}

\begin{abstract}
Subject of the article is devoted to the special economic zones (SEZs) creation or so-called points of accelerated growth in Russia. In the world practice one of the most widely used methods of increasing the national economies welfare, regions and solving local economic problems is the creation of special economic zones - territories with a special mode of economic activity, which is subject to a preferential business regime, and the free customs zone procedure can be applied. They are used as a way to attract investment as in developing countries and a tool for regional economic policy as in developed countries to stimulate depressed regions and solve problems of equalizing the economic development level.
\end{abstract}

\section{KEY WORDS}

Special economic zones, business development, competitiveness, public-private partnership, depressed regions, investment projects.

With the beginning of the market development relations in Russia and for two decades, the important tasks such as the transition to an innovative economy with high scientific and technical potential, the growth of production volumes with high added value, the withdrawal from the fuel industry remain unresolved and, therefore, always topical - the raw orientation of domestic exports, attracting direct investment in priority economic activities and preventing capital outflows abroad.

The analysis of foreign experience proves once again that the strategically important industries development is largely determined by state policy aimed at creating favorable conditions for investment, protecting the domestic market and improving the competitiveness of products. The set tasks achievement should be ensured by such well-established instruments worldwide as concessional lending and taxation, provision of state guarantees for external export production financing, a «package» provision of privileges and privileges to investors, and a policy of state assistance in promoting domestic products, both domestically and in the foreign market [1].

In the world practice, one of the most widely used methods of increasing the national economies welfare, regions and solving local economic problems is the creation of special economic zones - territories with a special mode of economic activity, which is subject to a preferential business regime, and the free customs zone procedure can be applied.

Special economic zones have a number of common features: it is part of the national territory, which has expanded autonomy in resolving economic issues, a special management regime and preferential conditions of economic activity for foreign and national enterprises. They are used as a way to attract investment (this applies to developing countries) and a tool for regional economic policy (using developed countries to stimulate depressed regions and solve problems of equalizing the economic development level) [2].

The world practice knows two alternative methods for creating special economic zones: 
1. According to the state program and mainly on budgetary funds, creation of special economic zones is managed by the departmental structure and provide for a permissive procedure for private investment (for example, China, Republic of Korea);

2. Special economic zones is managed by a legal entity in the form of a special company of private or mixed ownership, building relations with investors on a civil contractual basis with a declarative investment procedure. This form is more widely used in the world today [3].

Currently, several thousand similar territorial and economic entities function in the world, and their organizational and functional structure is quite diverse.

Russia also has experience in the creation, development and operation of special economic zones. The first attempts to create specialized territories in Russia were made in 1994, but this led to inconsistencies with the current legislation, and the projects were canceled. The full development of special economic zones in our country began in 2005 , the legal regulation of relations in the SEZ in the Russian Federation is carried out in accordance with the Federal Law of 22.07.2005 No. 116-FL "On Special Economic Zones in the Russian Federation». SEZs are created for a period of 49 years [4].

Today, special economic zones in Russia are created to develop high-tech and manufacturing industries, develop tourism, sanatorium and resort facilities, port and transport infrastructures, develop technologies and commercialize their results, and produce new types of products. Creation of special economic zones is economically justified for the state and is beneficial for entrepreneurs and investors. In Russia, each one is called upon to solve the most important strategic tasks. Attracting investment in a particular region contributes to its development. In addition, there is a bet on any industry and the direction of services, from the successful operation of which it is expected to replenish the budget, expand the opportunities for foreign trade.

By creating special zones, the state solves the following tasks:

1. Ensures the flow of private domestic and foreign capital.

2. Promotes an increase in the number of jobs, especially for highly qualified employees, which is necessary to motivate the best minds of the country to remain within it.

3. Realizes the import substitution rate, makes it possible to restore and create domestic production.

In turn, residents and companies registered in the zones territory can:

1. Reduce their production costs and administrative issues through reduced rates for customs duties, taxes, etc. This gives greater freedom in designating the price of the product, which increases its competitiveness.

2. To use the infrastructure created by the state, in most cases at the initial stage these expenses are carried out from the budget.

3. To have an advantage when choosing qualified specialists [5].

For 12 years of work in special economic zones more than 600 residents have registered, of which more than 100 companies are with foreign capital from 33 countries around the world. Over these years, the total volume of investments made amounted to 244 billion rubles, about 25,000 jobs were created, and about 35 billion rubles of tax deductions and contributions to extra-budgetary funds were paid, as well as 30 billion rubles of customs payments. Each special zone is endowed with a special legal status that gives special economic zones investors a number of tax benefits and customs preferences, as well as guarantees access to engineering, transport and business infrastructure. The costs of investors in the projects implementation in the SEZ are on average $30 \%$ lower than in the Russian Federation.

The special zones created comfortable conditions for business development, implementation of investment projects, and creation of new industrial and high-tech products.

Claim for the status of the special economic zones can be the territory that meets the following conditions: advantageous location (proximity to the borders of the country or to the regions with which cooperation is planned, access availability to the sea, places suitable for organizing recreation areas); availability of unoccupied areas, where it is possible to locate enterprises and complexes; the presence of a sufficient number of staff at the required 
qualifications level; openness to international and interregional contacts; appropriate sector focus [6].

Table 1 - Comparative characteristics of special economic zones in Russia

\begin{tabular}{|c|c|c|c|c|}
\hline & $\begin{array}{l}\text { Industrial-production } \\
\text { SEZ }\end{array}$ & $\begin{array}{l}\text { Technical and innovative } \\
\text { SEZ }\end{array}$ & $\begin{array}{l}\text { Tourist and } \\
\text { recreational SEZ }\end{array}$ & Port SEZ \\
\hline $\begin{array}{l}\text { Permitted } \\
\text { activities }\end{array}$ & $\begin{array}{l}\text { Projects in the sphere } \\
\text { of production and } \\
\text { logistics activities }\end{array}$ & $\begin{array}{l}\text { Projects in the sphere of } \\
\text { creation, production and sale } \\
\text { of scientific and technical } \\
\text { products, provision of } \\
\text { services for the } \\
\text { implementation and } \\
\text { maintenance of programs, } \\
\text { databases, topographies of } \\
\text { integrated microcircuits, } \\
\text { information systems; } \\
\text { projects on the provision of } \\
\text { innovative infrastructure } \\
\text { services to residents of the } \\
\text { special economic zones }\end{array}$ & $\begin{array}{l}\text { Projects in the } \\
\text { sphere of } \\
\text { construction, } \\
\text { reconstruction and } \\
\text { operation of objects } \\
\text { of sanatorium } \\
\text { treatment, medical } \\
\text { rehabilitation, etc. } \\
\text { Projects in the field } \\
\text { of development of } \\
\text { deposits of mineral } \\
\text { waters, therapeutic } \\
\text { muds and other } \\
\text { natural and } \\
\text { medicinal resources, } \\
\text { their extraction and } \\
\text { use, industrial } \\
\text { bottling of mineral } \\
\text { waters. }\end{array}$ & $\begin{array}{l}\text { Construction / } \\
\text { reconstruction of } \\
\text { infrastructure facilities of } \\
\text { sea and river ports, } \\
\text { airports; conducting } \\
\text { production and logistics } \\
\text { activities; creation of a p / } \\
\text { p for the production, } \\
\text { repair, maintenance, } \\
\text { modernization of sea and } \\
\text { river vessels, aviation } \\
\text { equipment; creation of a p } \\
\text { / p for the processing of } \\
\text { aquatic biological } \\
\text { resources, etc. }\end{array}$ \\
\hline $\begin{array}{l}\text { Investment } \\
\text { requirements }\end{array}$ & $\begin{array}{l}\text { Capital investments in } \\
\text { the amount of at least } \\
120 \text { million rubles. } \\
\text { (excluding intangible } \\
\text { assets) within } 3 \text { years } \\
\text { from the date of the } \\
\text { conclusion of the } \\
\text { Agreement on the } \\
\text { conduct of business. }\end{array}$ & $\begin{array}{l}\text { There are no minimum } \\
\text { requirements. }\end{array}$ & $\begin{array}{l}\text { There are no } \\
\text { minimum } \\
\text { requirements. }\end{array}$ & $\begin{array}{l}\text { The volume of investments } \\
\text { is at least } 400 \text { million } \\
\text { rubles. at construction and } \\
\text { not less than } 120 \text { million } \\
\text { rubles. at reconstruction of } \\
\text { objects of port } \\
\text { infrastructure. }\end{array}$ \\
\hline Tax breaks & $\begin{array}{l}\text { The profit tax is from } 2 \\
\text { to } 15.5 \% \text { (depending on } \\
\text { the SEZ region); } \\
\text { property tax }-0 \% \text { (for } \\
10 \text { years); land tax - } 0 \% \\
\text { (for } 5 \text { years); transport } \\
\text { tax }-0 \% \text { (from } 5 \text { to } 10 \\
\text { years) }\end{array}$ & $\begin{array}{l}\text { The profit tax is from } 2 \text { to } \\
15.5 \% \text { (depending on the } \\
\text { SEZ region); } \\
\text { property tax - } 0 \% \text { (for } 10 \\
\text { years); land tax - } 0 \% \text { (for } 5 \\
\text { years); transport tax - } 0 \% \\
\text { (from } 5 \text { to } 10 \text { years); benefits } \\
\text { on deductions to off-budget } \\
\text { funds: } \\
14 \% \text { until } 2017 \\
21 \% \text { until } 2018 \\
28 \% \text { until } 2019 \text {. }\end{array}$ & $\begin{array}{l}\text { The profit tax is from } \\
2 \text { to } 15.5 \% \\
\text { (depending on the } \\
\text { SEZ region); } \\
\text { property tax - } 0 \% \text { (for } \\
10 \text { years); } \\
\text { land tax - } 0 \% \text { (for } 5 \\
\text { years); benefits on } \\
\text { deductions to off- } \\
\text { budget funds: } \\
14 \% \text { until } 2017 \\
21 \% \text { until } 2018 \\
28 \% \text { until } 2019 \text {. }\end{array}$ & $\begin{array}{l}\text { The profit tax is from } 2 \text { to } \\
15.5 \% \text { (depending on the } \\
\text { SEZ region); } \\
\text { property tax - } 0 \% \text { (for } 10 \\
\text { years); } \\
\text { land tax - } 0 \% \text { (for } 5 \text { years); }\end{array}$ \\
\hline $\begin{array}{l}\text { Other } \\
\text { benefits and } \\
\text { preferences }\end{array}$ & $\begin{array}{l}\text { Privileged conditions for } \\
\text { leasing / redemption of } \\
\text { land plots; absence of } \\
\text { payment for technical } \\
\text { connection to } \\
\text { engineering networks; } \\
\text { allowed to conduct } \\
\text { technical and innovative } \\
\text { activities with the } \\
\text { provision of additional. } \\
\text { privileges on deductions } \\
\text { to off-budget funds } \\
\text { (decrease to } 14 \% \text { ); }\end{array}$ & $\begin{array}{l}\text { Benefits for renting office } \\
\text { and laboratory premises; } \\
\text { Privileged conditions for } \\
\text { leasing / redemption of land } \\
\text { plots; lack of payment for } \\
\text { technical connection to } \\
\text { engineering networks; }\end{array}$ & $\begin{array}{l}\text { Privileged conditions } \\
\text { for leasing / } \\
\text { redemption of land } \\
\text { plots; absence of } \\
\text { payment for } \\
\text { technical connection } \\
\text { to engineering } \\
\text { networks; }\end{array}$ & $\begin{array}{l}\text { Privileged conditions for } \\
\text { leasing / redemption of } \\
\text { land plots; absence of } \\
\text { payment for technical } \\
\text { connection to engineering } \\
\text { networks; }\end{array}$ \\
\hline $\begin{array}{l}\text { Special } \\
\text { customs } \\
\text { regime }\end{array}$ & $\begin{array}{l}\text { The customs procedure } \\
\text { of the "free customs } \\
\text { zone": the absence of } \\
\text { import duties and VAT } \\
\text { on imported } \\
\text { technological } \\
\text { equipment, materials, } \\
\text { components; a special } \\
\text { procedure for the } \\
\text { calculation and } \\
\text { payment of duties and } \\
\text { VAT on products } \\
\text { produced in the SEZ }\end{array}$ & $\begin{array}{l}\text { The customs procedure of } \\
\text { the "free customs zone": the } \\
\text { absence of import duties and } \\
\text { VAT on imported } \\
\text { technological equipment, } \\
\text { materials, components; a } \\
\text { special procedure for the } \\
\text { calculation and payment of } \\
\text { duties and VAT on products } \\
\text { produced in the SEZ }\end{array}$ & & $\begin{array}{l}\text { The customs procedure of } \\
\text { the "free customs zone": } \\
\text { the absence of import } \\
\text { duties and VAT on } \\
\text { imported technological } \\
\text { equipment, materials, } \\
\text { components; a special } \\
\text { procedure for the } \\
\text { calculation and payment of } \\
\text { duties and VAT on } \\
\text { products produced in the } \\
\text { SEZ }\end{array}$ \\
\hline
\end{tabular}


Special economic zones of the following types can be created on the Russia's territory: industrial-production special economic zones (SEZ PPT or PPZ); technical and innovative special economic zones (SEZ TVT or TVZ); tourist and recreational special economic zones (SEZ TRT or TRZ); port special economic zones (SEZ PT or PSEZ) [4].

Today, 26 special economic zones operated under the management of three management companies: JSC SEZ, OJSC KSK and JSC SEZ Titanium Valley.

To date, in Russia there are 10 industrial-production SEZs, the priority areas of activity, which are engineering; automotive industry; aircraft building; manufacture of vehicles, equipment and components; petrochemistry; pharmaceutical industry; Construction Materials; consumer goods, etc., with planned state investments in infrastructure from 5 to 20 billion rubles. Industrial special economic zones, such as "Alabuga», "Lipetsk», "Titanium Valley», «Togliatti» is a fairly large area located in large industrial regions of the country. Their relative proximity to the resource base for production and access to the finished infrastructure and transport routes are the main advantages of the PPT. The location of production on their territory allows to increase the products competitiveness on the market due to lower costs. For example, the industrial-production special zone "Alabuga» is located in the Republic of Tatarstan, near the federal highway and the railway branch. Occupies an area of 20 square meters. km, employs about 5000 employees. More than 40 enterprises of residents are engaged in the production of: buses, household appliances, medicines, furniture, complex chemicals, aircraft [7].

A prerequisite for residents is to make investments in the amount of 1000000 euros in the first year of operation, and 10000000 euros for the period for which the contract is concluded.

The advantages of business organization in «Alabuga» are: in the ability to locate and use foreign-made equipment without paying VAT and customs fees; in the exemption from the export duty for the export of manufactured products; in the absence of obligations to pay taxes on transport and land to the regional budget; in the benefits for income tax until 2055 $(2 \%$ - the first five-year plan, $7 \%$ - the second, $15.5 \%$ - the subsequent period) in the provision of reduced prices of land with a prepared infrastructure.

Location of technology-innovative special economic zones («Dubna», «Zelenograd», "St. Petersburg», "Tomsk») in the largest scientific and educational centers with rich scientific traditions and recognized research schools, opens large opportunities for the innovative business development, production of science-intensive products and its withdrawal to Russian and international markets. Providing a «package» of customs privileges and tax preferences, access to professional human resources, coupled with the growing demand for new technologies and the modernization of various sectors of the Russian economy, makes technological special zones attractive for venture funds, as well as developers and manufacturers of high-tech products. The territory of the technical-innovative zone "Dubna» in 200 hectares is divided into three fragments, each of which is allocated for programmers, nanotechnologists or nuclear physicists. The main activities include: nanotechnology, information development, development of nuclear physics, biotechnology, innovations in the field of medicine [8].

Residents of the special zone "Dubna» receive the following preferences: tax benefits (the first 5 years of payment is subject only to income tax transferred to the regional budget); simplified procedures for documenting land; subsidized connection to communications and rent; lack of customs restrictions.

Port special economic zones («Ulyanovsk-Vostochny», "Sovetskaya Gavan» and zone in the Murmansk region) are located in close proximity to global maritime trade routes and air corridors. Based on the main transport routes, logistics special zones can become a platform for organizing shipbuilding and shiprepairing activities, providing logistics services, as well as a base for new routes.

Tourist and recreational type of SEZ («Russian Island», Grand «Spa Yutsa», "Gate of Baikal», "Altai Valley», North Caucasus Tourist Cluster, etc.) being located in the most picturesque and sought-after tourists regions of Russia, offers favorable conditions for the organization of tourist, sports, recreational and other types of business. Also there are wide 
opportunities for the development of beach, adventure recreation, ecotourism, extreme sports.

Tourist and recreational SEZ "Turquoise Katun» is the largest in terms of the area occupied - 3326 hectares. This is the only project that really takes tourists today. 24 objects and the most part of the planned communication systems are constructed. Under the terms of the signed agreement, tax and administrative benefits are provided until 2055 [9].

But because of the revealed violation of the balance of capital investments by the state and private investors, the project can be transferred to the regional department or lose the status of a special zone. Despite on this, the influx of tourists is growing every year, and the entrepreneurs interest in the region is also increasing. In any case, as of the state of the territory for 2017, "Turquoise Katun» is attractive for business in terms of a prepared platform and comfortable conditions for renting land.

The Ministry of Economic Development of the Russian Federation has prepared a report on the results of the operation of special economic zones for 2016, as well as for the period since the beginning of the special economic zones operation.

According to the results of 2016, the best performance indicators for special zones of the technical-innovative type (96\% efficiency index), industrial-production type (95\%) and port type (94\%). The most effective for the entire period of SEZ existence are zones of industrial-production type $(100 \%)$ and technology-innovative type (99\%). The lowest efficiency indicators for the port zones (37\%) and tourist-recreational type (33\%) [10].

In October 2017, four Russian economic zones were noted in the annual global rating «Free Economic Zones - 2017» according to the authoritative international magazine fDi, which is part of the Financial Times group.

The number of Russian special zones included in the rating included the "Alabuga". It became the best economic zones in Europe for large residents for the third time in a row. In 2016, the rating compilers noted the expansion of the special economic zones infrastructure through the acquisition of the Yelabuga TPP and the Alabuga City Hotel. The management company SEZ «Alabuga» provides services for the construction of premises for rent in accordance with the requirements of the investor - build-to-suit. In addition, the second time in a row, "Alabuga» is mentioned in a similar nomination among the best in the world [11].

The special economic zone "Lipetsk» became the winner of the global rating of the special economic zones around the world in two categories: «SEZ of the year for expansion of projects» and "SEZ of the year for tax reforms». The victory in these nominations was awarded for increasing investment volumes and a significant lines expansion, as well as for effective efforts coordination with local tax and customs authorities in taxation matters and administration of resident companies.

The special economic zone of Togliatti was awarded for the third year in a nomination "Potential competitors». The rating notes that the special economic zone has made a breakthrough in terms of infrastructure construction, including customs, and in attracting and productive work with investors.

Among the "newcomers" of the fDi rating is the special economic zone "Titanium Valley». The Sverdlovsk zone became the only free zone in the world specializing in metallurgy, and also entered the list of SEZs that attracted the largest investors. The compilers of the rating separately singled out the Ural Boeing Manufacturing project - the joint production of Boeing and VSMPO-AVISMA corporations [11].

Along with the existing advantages, this instrument of structural policy requires serious refinement and resolution of organizational, regulatory, information and methodological issues. Within the framework of the state's structural policy, the economic zones have become a large-scale federal project aimed at developing the regions by attracting direct Russian and foreign investments in high-tech sectors of the economy, import substituting production, shipbuilding and tourism.

The possibility of solving many problems in Primorsky Krai can be the development of projects within the framework of public-private partnership (PPP) to create special economic zones of regional and municipal level. The creation of such zones is most relevant for projects that do not involve large investments in the basic infrastructure, large purchases of 
imported equipment and already having potential investors [12]. Today special economic zones are created for a period of 49 years with the right to purchase a land plot in the property at a reduced price after the project is implemented. Each special economic zones is endowed with a special legal status that gives investors a number of tax privileges and customs preferences (Table 1), and also guarantees access to engineering, transport and business infrastructure. It should be noted that the costs of investors in the implementation of projects in special economic zones are on average $30-40 \%$ lower than all-Russian indicators. The implementation of this idea on a municipal scale requires the introduction of the necessary changes in regional legislation and the organization of development and launch of investment projects.

Conclusion. From all of the above, it follows that the problem of managing various investment and innovation projects requires a consistent state policy to attract investment in the special economic zones on the public-private partnership principles, as well as the creation of an effective mechanism for its implementation. This task is particularly important for depressed areas, subsidized regions and single-industry towns, where the consequences of financial and economic crises are most negative.

Determination of priority directions for the region development (oblast, krai, city), the system development for selecting applicants for the creation of a special economic zones at the regional (municipal) level and a mechanism for customs and tax incentives will create favorable prerequisites for the development of domestic branches of the economy by attracting investments and creating new competitive industries.

Hydrocarbons export is not a sufficient condition for sustainable economic growth of the country. Consequently, Russia needs to provide competitive advantages in key sectors of the national economy, primarily at the local, regional level, and only then - at the federal and international levels. Stimulating the regions to form special economic zones for the development of the socio-economic base and greater participation of private business in the creation and management of the SEZ will ensure sustainable economy development and national competitiveness increase.

\section{REFERENCES}

1. Zimenkov R.I. (2011) Free economic zones: textbook. Moscow: Unity-Dana. 224 p.

2. Tinitskaya, O.V. Makarova, G.V. (2014) Free economic zones: tutorial: textbook. St. Peterbyrg: Intermedia. 250 p.

3. Movtsev V.V. (2008) Special economic zones // Invest Region No.4. - P. 2

4. Russian Federal Law «On Special Economic Zones in the Russian Federation», July 22, 2005 No. 116-FZ [Electronic resource] // Official site of «ConsultantPlus», URL: http://base.consultant.ru/cons/cgi/online.cgi?req=doc;base=LAW;n=142952

5. Kryukova E.V. (2010) Features of attracting foreign capital in analyzing the functioning of free economic zones. // Russian Entrepreneurship. Vol. 11. No. 11. P. 15-21.

6. Akhmetshina L.G. (2011) Principles and trends of the formation of special economic zones in the region // Journal of Russian Entrepreneurship. Vol. 12. No. 8. P. 150-154.

7. Special economic zones (2016), [Electronic resource] // Official site of Ministry of Economic Development, URL: http://economy.gov.ru/minec/activity/sections/sez/

8. Special economic zone «Dubna» (2017), [Electronic resource] // Official site of SEZ «Dubna», URL: http://dubna-oez.ru/about_oez/

9. Special economic zone «Turquoise Katun» (2016), [Electronic resource] // Official site of ROSSEZ, URL: http://www.russez.ru/oez/tourism/altai_territory/bir_katun/

10. Report on the results of the special economic zones operation for 2016 and the period since the beginning of the operation of special economic zones (2016), [Electronic resource] // URL: http://economy.gov.ru

11. SEZ of Russia entered the rating of the best in the world (2017), [Electronic resource] // Official site News Economy, URL: http://www.vestifinance.ru/articles/92795

12. Furshchik, M.A. Public-Private Partnership: New Instruments of Russian Structural Policy // Russian Economic Journal, No. 2, 2007. 